\title{
Effects of Depreciation and Appreciation of the Vietnamese Dong on Aggregate Output
}

\author{
Yu Hsing (Corresponding author) \\ College of Business, Southeastern Louisiana University, Hammond, Louisiana, USA \\ E-mail: yhsing@selu.edu \\ Minh Q. Huynh \\ College of Business, Southeastern Louisiana University, Hammond, Louisiana, USA \\ E-mail: minh.huynh@selu.edu
}

Received: March 19, 2019 Accepted: April 4, 2019 Published: April 17, 2019

doi:10.5296/ber.v9i2.14523 URL: https://doi.org/10.5296/ber.v9i2.14523

\begin{abstract}
Applying an extended IS-MP-AS model (Romer, 2000, 2006), this paper finds that real appreciation of the Vietnamese dong raised aggregate output during 2000-2012 whereas real depreciation of the Vietnamese dong increased aggregate output during 2013-2017. In addition, aggregate output is positively affected by the government debt-to-GDP ratio, the real stock price, and the real oil price and negatively influenced by the world real interest rate and the expected inflation rate. Therefore, real depreciation may affect aggregate output positively or negatively depending upon the stage of economic development.
\end{abstract}

Keywords: Real depreciation/appreciation, Government debt, Stock prices, World interest rates, Oil prices

\section{Introduction}

In a country once devastated by a series of prolonged wars, Vietnam has risen to be one of Asia' success stories with its economy posted an annual per capita growth of 5.3 percent since 1986 (Breu, et al, 2012). Its per capita income has increased six-fold from \$396 in 2000 to $\$ 2,385$ in 2017 (Boudreau, 2018). Such a remarkable growth rate is faster than any other Asian economy apart from China (Breu, et al, 2012). In recent years, Vietnam boasts to be one of the world's fastest-growing economies, optimistic citizens and a stable government (Boudreau, 2018). According to the report from General Statistics Office in Hanoi, its impressive economic growth is at 6.3 percent between 2005 and 2017. The pace of growth 
seems unabated when the economy grew 7.38 percent in the first quarter of 2018. The World Bank revised its forecast on Vietnam's 2018 economic growth to 6.8 percent from 6.5 percent (Boudreau, 2018).

The booming economy is in part being driven by investments from foreign companies (Nguyen, June 13, 2018; Nguyen June 13, 2018). Recently, the country was able to attract global companies such as Samsung Electronics Co., LG Electronics and Nestle SA. These companies along with others have come and made substantial investments in Vietnam because of the country's young and low-cost workforce. The growing foreign investment has in turn helped Vietnam to emerge as Asian's manufacturing powerhouse (Nguyen, March 13, 2018).

In addition to attracting foreign investment, Vietnam is also actively plowing ahead on free trade agreements with other countries. Its strategy is to diversify markets and products in order to boost its vibrant export (Nguyen, March 13, 2018). While U.S. is Vietnam's largest export market with a fifth of its export goods, the country is seeking trades with others including Japan, nearby Asian countries, as well as Europe. Despite the withdrawal of the U.S., on March 8, 2018, Vietnam joined 10 other countries to sign a Trans Pacific trade pact as an effort to expand the reach of its export (Nguyen, March 13, 2018).

Can Vietnam sustain its impressive growth? If so, how? Within the context of this question, the answer could be projected by assessing the two factors that underpin the impressive economic growth in Vietnam. They are (1) the inflow of foreign investment and (2) the outflow of export goods to other countries. These factors are in turned influenced much by the fluctuation of currency exchange and aggregate output. The scope of this study will focus specifically on effects of depreciation and appreciation of the Vietnamese dong on aggregate output. This key variable is the exchange rate of "dong", the official currency of Vietnam. The primary goal for the study is to examine whether real depreciation or real appreciation of dong would raise aggregate output or not. If so, what are the role of other related variables on this relationship? The study will consider also other related variables including government debt-to-GDP ratio, U.S. real prime lending rate, real stock price, real crude oil price, and expected inflation rate and their impacts on the real GDP. To gain insight of these variables' impact on GDP, we are going to apply the IS-MP-AS model (Romer, 2000, 2006) as our theoretical framework for the analysis. An important feature of the IS-MP-AS model is that it incorporates the monetary policy function (Taylor, 1993, 1999), in which the central bank's policy rate responds to the inflation gap, the output gap and other related variables. Hopefully, by examining how the currency depreciation and appreciation effect aggregate output in the context of other related variables would help us understand the inner mechanism that drives the country's inflow of foreign investment and its outflow of goods export. Hence, the results may shed some insights on the answer of whether Vietnam can sustain its growth or not. Furthermore, the results may also suggest some of the practical implications on what economic policy and strategy Vietnam could pursue to remain its impressive growth.

\section{Background Context}

Vietnam aims at maintaining its gross domestic product growth at around 7 percent. 
According to the International Monetary Fund, the growth rate of its real GDP was $6.5 \%$ in 2017 and has been more than 6\% since 2015. Even during the global financial crisis, its growth rate was still more than 5\% in 2008 and 2009. The unemployment rate was $2.4 \%$ in 2017 and has been less than 3\% since 2012. These strengths could be derived from the growth in export. As observed, exports were greater than imports during this time period. Furthermore, its current account had a surplus of 4.07\% of GDP in 2017. Finally, the export sector has created many job opportunities.

Despite its robust growth, Vietnam's economy shows areas of fragility. One of such concerns is the rise of protectionism as evidenced by the recent imposition of trade tariff by President Trump. Other countries threatened to respond with similar actions. All trade tariff responses are expected to impact the export-oriented economies like Vietnam. Another concern is the sign of slowdown in major world markets such as U.S., China, and Europe where Vietnam's export depends on. These are a few of the many challenges that Vietnam faces. In order to remain one of the world's fastest-growing economies, its government may need to closely monitor these global trends and at the same time continue to nurture an environment attractive to foreign capitals. Internally, the government may want to pursue policies that maintain fast growth while keeping inflation under control (Nguyen, June 13, 2018). Furthermore, the government may also need to carefully tracking and managing its current exchange because of its impact on the real GDP growth rate.

The Vietnamese dong has lost value versus the U.S. dollar in the long run, changing from 6,537.60 dong per U.S. dollar in 1990 to 22,717.29 in 2017. Whether depreciation of the Vietnamese dong would be beneficial to aggregate output remains little known. This study hopes to look into and gain some insight in the role of dong's depreciation and appreciation and their impact on the real GDP. In addition, this study also takes into consideration other important variables related to the growth of real GDP. One of such variables is the level of government spending. The concern was Vietnam's relatively high government spending as a percent of GDP, reaching $28.952 \%$ in 2017. A related concern was its rising government debt-to-GDP ratio from $31.432 \%$ in 2000 to a high of $63.424 \%$ in 2017 , which was greater than the $60 \%$ criterion in the European Union. Whether a rising government debt-to-GDP ratio may help or harm aggregate output is a related dimension that this study wants to examine. The inflation rate of $4.869 \%$ in 2017 was slightly higher than many industrialized countries but much lower than those during the hyperinflation times in 1986-1988. Whether this relatively high inflation rate has any impact on the growth rate of real GDP is another related dimension that this study will explore. In comparison, Vietnam's growth rate of real GDP, the inflation rate, the government spending as a percent of GDP and the government debt-to-GDP ratio were higher than those in Indonesia, Malaysia and Thailand. Its unemployment rate was lower than those in Indonesia and Malaysia and slightly higher than that in Thailand.

Therefore, the key focus of this study is to examine whether real depreciation or real appreciation would raise aggregate output or not. Furthermore, the study considers also other related variables; namely, government debt-to-GDP ratio, U.S. real prime lending rate, real stock price, real crude oil price, and expected inflation rate using the IS-MP-AS model 
(Romer, 2000, 2006) as the theoretical framework for the analysis.

\section{Literature Survey}

Several recent studies have examined the effects of exchange rate movements on output, inflation, exports, imports and other related variables for Vietnam or related countries. Using a sample during 1992.M1 - 2005.M4 in the core model and applying the VAR technique, Vinh and Fujita (2007) reveal that real depreciation raised output and inflation in Vietnam via improving the trade balance and raising the money supply in the short run and had no effect on output in the long run and that the real exchange rate had more influence on output than the price level.

Le and Vinh (2011) study the impacts of the real effective exchange rate, the oil price and inflation on industrial production in Vietnam using a monthly sample during 1995-2009. Depreciation or a higher oil price affected industrial production positively, and the exchange rate had more influence than the oil price. A higher inflation rate raised industrial production positively. But the coefficient of the inflation rate had a weak significance.

Pham (2016) reveals that devaluation raised output in the short run and long run and that the exchange rate also played a minor role in the change in the inflation rate.

Thanh and Kalirajan (2006) indicate that devaluation of the Vietnamese dong could be used to stimulate exports and improve the balance of payment and the current account in the short run and long run and also reduced appreciation of the real exchange rate in the short run.

Alemu and Jin-sang (2014) examine the impact of depreciation on the trade balance in selected Asian countries including Vietnam. In the 14-country sample, there was no evidence that depreciation would improve the trade balance because of strong reliance on imported goods, which may become more expensive measured in the local currency or because the terms of trade for manufactured or primary goods deteriorated. In the 8-country sample, depreciation improved the trade balance.

Using a monthly sample during 2008-2012, Nguyen (2014) examines the effect of real depreciation on the trade balance in Vietnam. He shows that the J-curve could not be confirmed, that real depreciation affected the trade balance negatively, and that the real exchange rate was not significantly involved in the determination of the trade balance.

Applying the SVAR and VECM techniques and using a monthly sample during 2004-2015, Hoang (2016) finds that the real effective exchange rate had very small effects on international trade in the short run, did not impact imports in real or nominal terms in the long run, and had a strong impact on exports in nominal terms in the long run.

Applying the ARDL technique and the error-correction model, Bao and Van (2018) show that real depreciation hurt the trade balance in Vietnam in the short run but improved the trade balance in Vietnam in the long run. These results suggest the existence of a J-curve.

\section{The Model}

Extending Romer (2000, 2006), we can express the IS-MP-AS model as: 


$$
\begin{gathered}
Y=u(Y, G, T, L(R), S, \varepsilon) \\
R=v\left(\pi-\alpha, Y-Y^{p}, R^{w}, \varepsilon\right) \\
\pi=w\left(\pi^{e}, Y-Y^{p}, E, \varepsilon\right)
\end{gathered}
$$

where

$$
\begin{aligned}
& \mathrm{Y}=\text { real GDP in Vietnam, } \\
& \mathrm{G}=\text { government spending, } \\
& \mathrm{T}=\text { government tax revenue, } \\
& \mathrm{L}=\text { the real lending rate, } \\
& \mathrm{S}=\text { the real stock price, } \\
& \varepsilon \quad=\text { the real exchange rate (units of the dong per U.S. dollar times relative prices in the U.S. } \\
& \text { and Vietnam), }
\end{aligned}
$$$$
\mathrm{R}=\text { the policy rate, }
$$$$
\pi=\text { the inflation rate, }
$$$$
\alpha=\text { the inflation target, }
$$$$
Y^{p}=\text { potential real GDP, }
$$$$
R^{w}=\text { the world real interest rate, }
$$$$
\pi^{e}=\text { the expected inflation rate, and }
$$$$
\mathrm{E}=\text { the real energy cost. }
$$

Suppose that the inflation target and potential real GDP are constants in the short run. Solving for $Y, R$ and $\pi$ simultaneously, we obtain equilibrium real GDP:

$$
Y^{*}=x\left(\varepsilon, G-T, R^{w}, S, E, \pi^{e}\right)
$$

As people are more concerned about government debt (D) in the long run, which is an accumulation of the government deficit $G-T$, we replace $G-T$ with $D$ in equation (4):

$$
\begin{gathered}
Y^{*}=x\left(\varepsilon, D, R^{w}, S, E, \pi^{e}\right) \\
? ?-\quad+?-
\end{gathered}
$$

Real depreciation tends to stimulate exports, reduce imports, raise import costs, increase domestic inflation, and reduce net capital inflows. The increase in net exports tends to shift aggregate demand to the right, the decrease in net capital inflows tends to shift aggregate demand to the left, and the increase in import costs and domestic inflation tends to shift aggregate supply to the left. Hence, the net impact is uncertain and needs to be determined empirically. 


\section{Macrothink}

Business and Economic Research

ISSN 2162-4860

2019, Vol. 9, No. 2

More government deficit spending increases government debt, which may raise the interest rate and dampen private spending. The increase in government debt- or deficit-financed spending shifts aggregate demand to the right, and the decrease in private spending due to the crowding-out effect shifts aggregate demand to the left. Therefore, the net impact is unclear. Barro $(1974,1989)$ indicates that the impact of government deficit- or debt-financed spending is neutral in the long run. Cebula (1997, 2014a, 2014b) and Cebula and Cuellar (2010) show that more government budget deficits raise the interest rate and tend to reduce private spending.

A higher world real interest rate raises the domestic real interest rate, reduces domestic private spending and aggregate demand. A higher real energy cost shifts short-run aggregate supply to the left. If it is a demand-driven, aggregate demand would shift to the right. The net effect is unknown (Kilian, 2008a, 2008b). A higher expected inflation rate shifts short-run aggregate supply to the left, raises the inflation rate, and reduces real GDP.

Figure 1 shows that the relationship between real GDP and the real exchange rate seemed to be nonlinear, being negative during 2000-2012 and positive during 2013-2017. Figure 2 indicates that real GDP and the government debt-to-GDP ratio seemed to have a positive relationship. Hence, a slope binary variable and an intercept binary variable are added to the estimated equation:

$$
Y^{*}=x\left(\varepsilon, \varepsilon \times B, B, D, S, R^{w}, E, \pi^{e}\right)
$$

where $\mathrm{B}=0$ during 2000-2012 and $\mathrm{B}=1$ during 2013-2017. Suppose that $\delta_{1}$ and $\delta_{2}$ are the respective estimated coefficients of $\varepsilon$ and $\varepsilon \times B$. It can be shown that the partial derivative of $Y^{*}$ with respect to $\varepsilon$ equals $\delta_{1}$ during 2000-2012 and $\delta_{1}+\delta_{2}$ during 2013-2017.

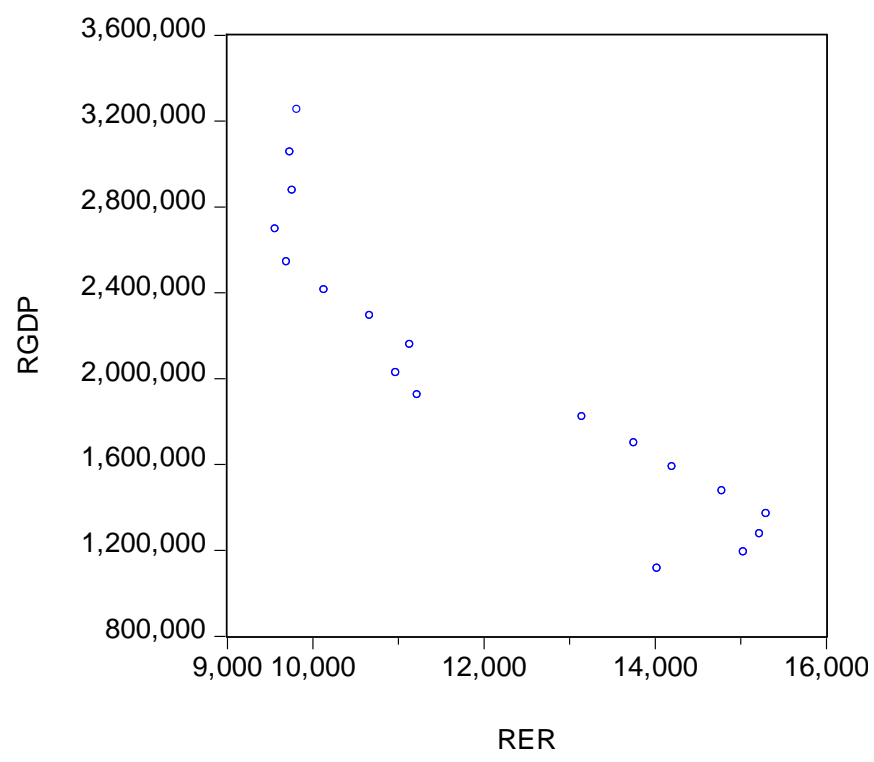

Figure 1. Scatter Diagram between Real GDP (RGDP) and the Real Exchange Rate (RER). Sources: The International Financial Statistics and the World Economic Outlook, International Monetary Fund 


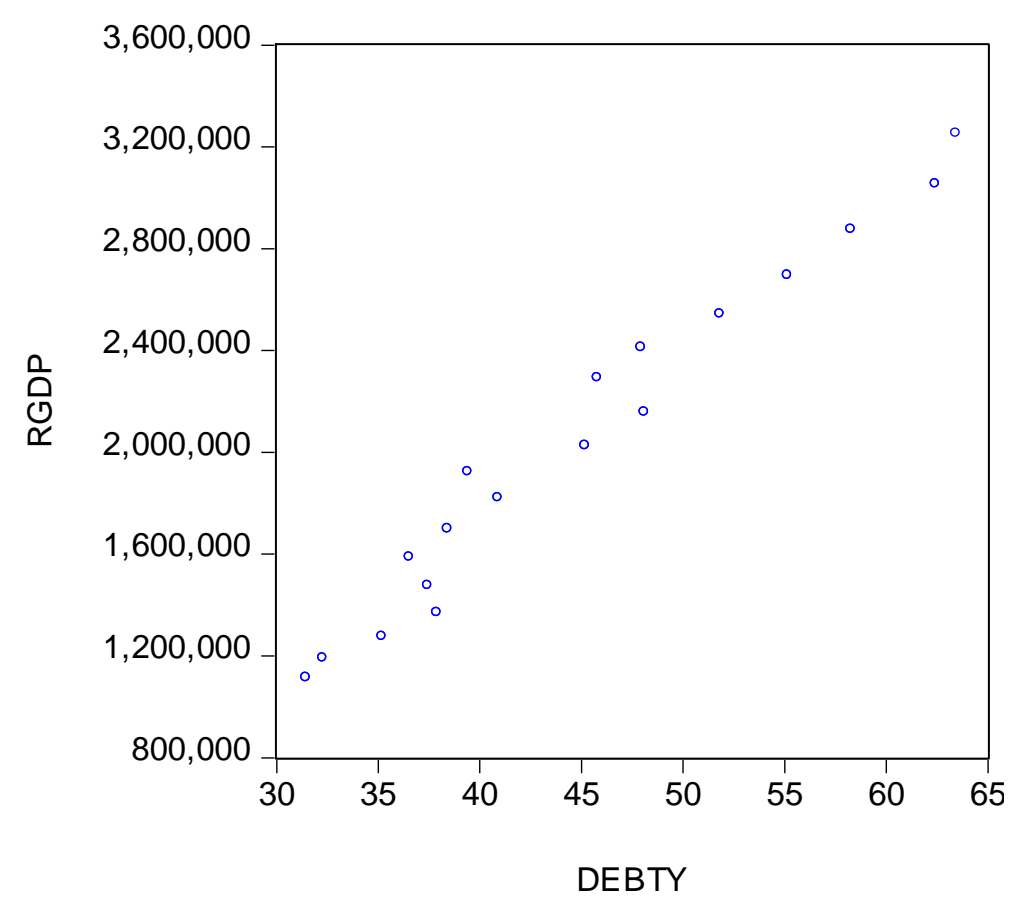

Figure 2. Scatter Diagram between Real GDP (RGDP) and the Government Debt-to-GDP Ratio (DEBTY). Sources: The International Financial Statistics and the World Economic Outlook, International Monetary Fund

\section{Empirical Results}

The data were collected from the World Economic Outlook and the International Financial Statistics published by the International Monetary Fund. Real GDP is measured in billion dongs. Ideally, a trade-weighted real exchange rate would be more appropriate as Vietnam has many trading partners. However, the data are unavailable. Hence, this study uses the real exchange rate, which equals the nominal exchange rate defined as units of the Vietnamese dong per U.S. dollar times the relative prices in the U.S. and Vietnam. Government debt is expressed as a percent of GDP. Because the U.S. prime lending rate has a one-for-one relationship with the U.S. federal funds rate, the real prime lending rate in the U.S. is chosen to represent the world real interest rate. The real stock price is measured as the equity price adjusted by the consumer price index. The real energy cost is represented by the crude oil price measured in the dong and adjusted by the consumer price index. The expected inflation rate is represented by the average inflation rate of the past three years. The sample period ranges from 2000 to 2017. The data for government debt are unavailable before year 2000 .

To test whether these time series variables may have a long-term stable relationship, the DF-GLS unit root rest on the regression residual is employed. The value of the test statistic is estimated to be -4.9826 , and the critical value is -3.7700 at the $1 \%$ level. Hence, these variables are cointegrated.

The EGARCH model is employed in empirical work in order to correct for potential autoregressive conditional heteroskedasticity. The advantages of EGARCH are that it does not have nonnegative restrictions on the parameters and that the conditional variance is 
specified as an asymmetric function of the lagged disturbances.

Table 1 presents empirical results. The eight exogenous variables can explain approximately $99.31 \%$ of the change in real GDP. The mean absolute percent error of $2.1375 \%$ indicates that the forecast error is relatively small. All the coefficients are significant at the $1 \%$ level. Real GDP is positively associated with the real exchange rate during 2013-2017, the debt-to-GDP ratio, the real stock price and the real oil price, and it is negatively affected by the real exchange rate during 2000-2012, the intercept binary variable, the U.S. real prime lending rate and the expected inflation rate.

Specifically, a $1 \%$ real depreciation of the dong would reduce real GDP by $0.5821 \%$ during 2000-2012 but increase real GDP by $2.4138 \%$ during 2013-2017. These results suggest that the positive effect of real depreciation on real GDP during 2013-2017 is greater than the negative effect of real depreciation on real GDP during 2000-2012.

If the debt/GDP ratio rises $1 \%$, real GDP would increase by $1.1329 \%$. A $1 \%$ increase in the real oil price would raise real GDP by $0.1749 \%$. The positive significant coefficient of the real stock price suggests that rising real stock prices tend to increase household real wealth and real consumption spending. The negative significant coefficient of the U.S. real prime lending rate implies that the central bank of Vietnam responds to U.S. monetary policy positively.

In comparison, the results in this paper during 2013-2017 are consistent with Vinh and Fujita (2007) in the short run, Le and Vinh (2011) and Pham (2016) whereas the results during 2000-2012 are in contrast with Vinh and Fujita (2007), Le and Vinh (2011), and Pham (2016).

Table 1. Estimated Regression of Log(Real GDP) in Vietnam

\begin{tabular}{|l|l|l|l|}
\hline Variable & Coefficient & z-Statistic & Probability \\
\hline Constant & 13.21952 & 995.4017 & 0.0000 \\
\hline Log(real exchange rate) & -0.582064 & -254.1466 & 0.0000 \\
\hline Log(real exchange rate) x Binary variable & 2.995895 & 545.8619 & 0.0000 \\
\hline Binary variable & -27.52572 & -618.8749 & 0.0000 \\
\hline Log(government debt-to-GDP ratio) & 1.132860 & 153.9822 & 0.0000 \\
\hline U.S. real prime lending rate & -0.003930 & -5.950808 & 0.0000 \\
\hline Log(real stock price) & 0.038472 & 632.3235 & 0.0000 \\
\hline Log(real crude oil price) & 0.174931 & 224.3068 & 0.0000 \\
\hline Expected inflation rate & -0.006869 & -10.99114 & 0.0000 \\
\hline R-squared & 0.993069 & & \\
\hline Akaike information criterion & -3.711207 & & \\
\hline Schwarz criterion & -3.167091 & & \\
\hline Methodology & EGARCH & & \\
\hline Mean absolute percent error & $2.137509 \%$ & & \\
\hline Sample period & $2000-2017$ & & \\
\hline Number of observations & 18 & & \\
\hline
\end{tabular}




\section{Summary and Conclusions}

This paper has examined the effects of real depreciation/appreciation of the Vietnamese dong and other related variables on real GDP in Vietnam. An extended IS-MP-AS model is applied, and the EGARCH process is used in empirical work. Real appreciation raised real GDP during 2000-2012 whereas real depreciation increased real GDP during 2013-2017. A higher government debt-to-GDP ratio, a lower U.S. real prime lending rate, a higher real stock price, a higher real crude oil price or a lower expected inflation rate would raise real GDP.

Although a higher government debt-to-GDP ratio raises real GDP, there may be a threshold beyond which a further increase in the debt-to-GDP ratio may reduce real GDP. The implication is that the Vietnam government should monitor its debt more closely and pursue a sustainable fiscal policy. For instance, in 2018, Vietnam's budget deficit was around 4.6 percent of gross domestic product. This is a relatively high ratio when compared to the median of 3.2 percent in economies rated BB (Nguyen, March 13, 2018). Hence, one of the practical strategies is to reduce the government's budget deficit in order to maintain a desirable government debt-to-GDP ratio.

To maintain its fast growth, Vietnam's government realized how important it is to keep its inflation under control. The government has taken concrete steps to contain inflation. For instance, it subsidized rising fuel costs in order to stabilize electricity prices. All of these measures would help to manage inflation and hence not to dampen the growth of real GDP.

It is more difficult for Vietnam to control the U.S. real prime lending rate and the real crude oil price because they are external to Vietnam. However, the government could monitor these variables in order to determine how much the impacts they would have and hence come up with appropriate responses to the changes.

Vietnam has much potential to grow if its government knows how to take the appropriate measures and when to implement them. The following are among the possible measures to take:

(1) boosting private companies by reducing the number of licenses; (2) helping businesses to cut costs by expediting the process of obtaining permits; (3) improving foreign investors' confidence by intensifying its corruption fight (Nguyen, March 13, 2018); (4) reforming state-owned enterprises; (5) managing non-performing loans more closely; (6) improving the transparency of provincial government; (7) diversifying markets and products to boost exports; and (8) transitioning from the economic model based on low-cost workforce to a value-added model in order to ensure that future business and finance are sufficiently robust to withstand slow growth, economic volatility, and increase in protectionism.

\section{Acknowledgement}

The draft paper was presented at the annual conference of the Southwestern Society of Economists, the Federation of Business Disciplines, Houston, Texas, March 15, 2019. Valuable comments made by session participants are appreciated. 


\section{References}

Alemu, A. M., \& Jin-sang, L. (2014). Examining the effects of currency depreciation on trade balance in selected Asian economies. International Journal of Global Business, 7, 59.

An, P. S., Hoi, C. M., \& Chi, T. T. K. (2016). Economic growth and macroeconomic stability of Vietnam. Economic Studies, 25, 135-144.

Anwar, S, \& Nguyen, L. P. (2018). Channels of monetary policy transmission in Vietnam. Journal of Policy Modeling, 40, 709-729.

Bao, H. H. G., \& Van, D. T. B. (2018). Testing J-curve phenomenon in Vietnam: An autoregressive distributed lag (ARDL) approach. In International Econometric Conference of Vietnam. Springer, Cham, January, 491-503.

Barro, R. J. (1974). Are government bonds net wealth? Journal of Political Economy, 82, 1095-1117.

Barro, R. J. (1989). The Ricardian approach to budget deficits. Journal of Economic Perspectives, 3, 37-54.

Boudreau, J. (2018). In Vietnam, discontent lurks under surface of economic success. Bloomberg. June 18. [Online] Available:

https://www.bloomberg.com/news/articles/2018-06-18/in-vietnam-discontent-lurks-under-sur face-of-economic-success

Breu, M., Dobbs, R., \& Remes, J. (2012). Taking Vietnam's economy to the next level. McKinsey \& Company. February. [Online] Available:

https://www.mckinsey.com/featured-insights/asia-pacific/taking-vietnams-economy-to-the-ne xt-level

Cebula, R. J. (1997). An empirical note on the impact of the federal budget deficit on ex ante real long term interest rates, 1973-1995. Southern Economic Journal, 63, 1094-1099.

Cebula, R. J. (2014a). Impact of federal government budget deficits on the longer-term real interest rate in the US: Evidence using annual and quarterly data, 1960-2013. Applied Economics Quarterly, 60, 23-40.

Cebula, R. J. (2014b). An empirical investigation into the impact of US federal government budget deficits on the real interest rate yield on intermediate-term treasury issues, 1972-2012. Applied Economics, 46, 3483-3493.

Cebula, R. J., \& Cuellar, P. (2010). Recent evidence on the impact of government budget deficits on the ex-ante real interest rate yield on Moody's Baa-rated corporate bonds. Journal of Economics and Finance, 34, 301-307.

Hiep, N. Q., \& Nha, N. T. (2016). Real effective exchange rate: A transmission channel for the impact of economic growth on exports in Vietnam. Journal of Economic Development, 23, 121-136. 


\section{Macrothink}

Business and Economic Research ISSN 2162-4860 2019, Vol. 9, No. 2

Hoang, L. H. (2016). The role of exchange rate in supporting trade balance in Vietnam (No. 16-2016). Graduate Institute of International and Development Studies Working Paper.

Kilian, L. (2008a). The economic effects of energy price shocks. Journal of Economic Literature, 46, 871-909.

Kilian, L. (2008b). Not all oil price shocks are alike: Disentangling demand and supply shocks in the crude oil market. CEPR Discussion Paper No. 5994.

Le, V. T., \& Vinh, N. T. T. (2011). The impact of oil prices, real effective exchange rate and inflation on economic activity: Novel evidence for Vietnam. Research Institute for Economics \& Business Administration, No. DP2011-09, Kobe University.

Nguyen, N. M. (2014).The impact of real exchange rate to trade balance in Vietnam (December 19). [Online] Available: SSRN: https://ssrn.com/abstract=2926335 or http://dx.doi.org/10.2139/ssrn.2926335.

Nguyen, D. (2018). Not even Trump can slow Vietnam's economy, official says. Bloomberg. March 13. [Online] Available:

https://www.bloomberg.com/news/articles/2018-03-14/not-even-trump-can-stop-vietnam-s-sp eedy-economy-official-says

Nguyen, D. (2018). Vietnam must tread carefully to win investment grade, Fitch says. Bloomberg. June 13. [Online] Available:

https://www.bloomberg.com/news/articles/2018-06-13/vietnam-must-tread-carefully-to-win-i nvestment-grade-fitch-says

Pesaran, M., Shin, Y, \& Smith, R. (2001). Bounds testing approaches to the analysis of level relationships, Journal of Applied Econometrics, 16, 289-326.

Pham Anh, T. (2016). Monetary policies and the macroeconomic performance of Vietnam. Doctoral dissertation, Queensland University of Technology.

Romer, D. (2000). Keynesian macroeconomics without the LM curve. Journal of Economic Perspectives, 14, 149-169.

Romer, D. (2006). Advanced Macroeconomics. New York: McGraw-Hill.

Taylor, J. B. (1993). Discretion versus policy rules in practice. Carnegie Rochester Conference Series on Public Policy, 39, 195-214.

Taylor, J. B. (1999). A historical analysis of monetary policy rules. In Monetary Policy Rules (319-348). University of Chicago Press.

Trang, N. T. N., Tho, T. N., \& Hong, D. T. T. (2017). The impact of oil price on the growth, inflation, unemployment and budget deficit of Vietnam. International Journal of Energy Economics and Policy, 7, 42-49.

Thanh, N. N., \& Kalirajan, K. (2006). Can devaluation be effective in improving the balance of payments in Vietnam?. Journal of policy modeling, 28, 467-476. 
Vinh, N. T. T. (2011). The impact of oil prices, real effective exchange rate and inflation on economic activity: Novel evidence for Vietnam (No. DP2011-09).

Vinh, N. T. T. (2015). The role of different channels in transmitting monetary policy into output and price in Vietnam. Journal of Economics and Development, 17, 20-40.

Vinh, N. T. T., \& Fujita, S. (2007). The impact of real exchange rate on output and inflation in Vietnam: A VAR approach.

\section{Copyright Disclaimer}

Copyright for this article is retained by the author(s), with first publication rights granted to the journal.

This is an open-access article distributed under the terms and conditions of the Creative Commons Attribution license (http://creativecommons.org/licenses/by/3.0/). 